\title{
Effect of calcitor fertilizer and neem leaf extract concentration on production and quality of siam orange fruits
}

\author{
Ni Komang Alit Astiari 1, ${ }^{*}$, Ni Putu Anom Sulistiawati ${ }^{1}$, I Nengah Suaria ${ }^{1}$ and I Nyoman Rai 2 \\ ${ }^{1}$ Agrotechnology Study Program, Faculty of Agriculture, Warmadewa University, Denpasar, Bali, Indonesia. \\ ${ }^{2}$ Agroecotechnology Study Program, Faculty of Agriculture, Udayana University, Denpasar, Bali, Indonesia.
}

Magna Scientia Advanced Biology and Pharmacy, 2021, 04(01), 019-024

Publication history: Received on 16 July 2021; revised on 24 August 2021; accepted on 26 August 2021

Article DOI: https://doi.org/10.30574/msabp.2021.4.1.0035

\begin{abstract}
This research was conducted in Belancan Village, Kintamani District, Bangli Regency, Bali, Indonesia, from December 2020 to July 2021, which aimed to increase production and fruits quality of Siam orange with calcitor fertilizer and concentration of neem leaf extract. The study used a randomized block design, factorial with 2 factors and 3 replications. The first factor was calcitor fertilizer consisting of 4 concentration levels, i.e., $0 \mathrm{cc} / \mathrm{l} / \operatorname{tree}\left(\mathrm{K}_{0}\right) ; 2 \mathrm{cc} / \mathrm{l} / \mathrm{tree}\left(\mathrm{K}_{1}\right), 4$ $\mathrm{cc} / \mathrm{l} /$ tree $\left(\mathrm{K}_{2}\right)$, and $6 \mathrm{cc} / \mathrm{l} /$ tree $\left(\mathrm{K}_{3}\right)$, while the second factor was neem leaf extract consisting of 3 concentration levels, i.e., $0 \%\left(\mathrm{M}_{0}\right), 5 \%\left(\mathrm{M}_{1}\right)$, and $10 \%\left(\mathrm{M}_{2}\right)$. The results showed that the interaction between calcitor fertilizer and neem leaf extract concentration had no significant effect on all observed variables. Calcitor fertilizer with a concentration of 6 $\mathrm{cc} / \mathrm{l} /$ tree could improve the quality of Siam orange fruit, which was reflected by the increase in the number of fruit per tree (106.44 fruit), weight per fruit (114.08 g), weight of fruit per tree $(14.37 \mathrm{~kg})$, fruit diameter $(6.89 \mathrm{~cm})$ and total dissolved solids (11.52 \%brix) or increased by $27.56 \%, 7.54 \% ; 40.74 \% ; 12.58 \%$ and $44.72 \%$, respectively, than those of control. While in the treatment of neem leaf extract at a concentration of $10 \%$ increase the number of fruit per tree (107.73 fruit), weight per fruit (117.44 g), fruit weight per tree $(16.04 \mathrm{~kg})$, fruit diameter $(7.58 \mathrm{~cm})$ and total dissolved solids (10.83\% brix), or an increase of $69.44 \% ; 18.76 \% ; 78.84 \%$ and $42.31 \%$, respectively, than those of control.
\end{abstract}

Keywords: Extract neem leaves; Calcitor; Fruit; Siam orange; Spraying

\section{Introduction}

Siam orange (Citrus nobilis var. Microcarpa Hassk) is one of the most widely cultivated citrus species and very potential to be developed in Indonesia to fulfill consumer demand. Around $70-80 \%$ of oranges developed by Indonesian farmers are Siam oranges. It's very popular because they have a sweet taste, contain high levels of vitamin C, and have a smooth and shiny skin surface [1]. National citrus production (Tangerine, Siam, Pamelo) in 2019 reached 2,510,420 tons or grew from 2015 of $9.37 \%$. To encourage increased production, the government through the Ministry of Agriculture of Indonesia in 2016 designated more than 50 cities/districts as National Area Development Locations for citrus commodities [2].

The obstacles faced by Siam orange farmers today are that their production is seasonal (not continuous) and the quality of the fruit produced is low. This happens because the maintenance carried out by farmers is less intensive, especially fertilization that is not balanced and not according to recommendations, both regarding the type of fertilizer and the time and method, and no action is taken to improve fruit quality. The potential production of Siam orange can reach 25 tons/ha [3], but according to [4] and [5], the production only reached 2.9 tons/ha or $40-70 \mathrm{~kg} /$ tree. Low quality of the Siam orange fruits indicated by non-uniform fruit size, yellow color of the orange peel which is often uneven, the skin

\footnotetext{
${ }^{*}$ Corresponding author: Ni Komang Alit Astiari

Agrotechnology Study Program, Faculty of Agriculture, Warmadewa University, Denpasar, Bali, Indonesia. 
of the fruit is not smooth, scars from mottled pests and diseases. dullness, and an especially inconsistent taste of sweetness.

According to [6] and [7], fertilization with organic fertilizers and fertilizers containing nutrients $\mathrm{N}, \mathrm{P}, \mathrm{K}, \mathrm{Ca}$ and $\mathrm{Mg}$ with the right dose and time of application can increase the productivity of citrus plants. Fertilization with $\mathrm{N}, \mathrm{P}$ and $\mathrm{K}$ fertilizers is usually done by farmers in the form of Urea, TSP, and $\mathrm{KCl}$ but the application of Ca and Mg fertilizers is still rarely applied, even though these two fertilizers are very important to increase the production and quality of Siam orange fruit. Khayat HME et al. and Yadav MK et al. reported that, calcium (Ca) fertilizer has the function of strengthening plants (not easily infected with fungi or bacteria), longer shelf life of fruit (thicker cell wall effect), and so reducing flowers and fruits drop and fruits cracked. While the Mg functions are assisting the photosynthesis process, helps the formation of chlorophyll which is very important in photosynthesis and supports plant permeability, increases plant resistance or immunity to pests and diseases, increases formation of sugars, carbohydrates, fats, proteins, oils, as well as leaf green matter and increases plant productivity (because magnesium fertilizer can prevent the fall of flowers and ovules) [8] [9]. According to [10], addition of calcium and magnesium fertilizers in the form of dolomite at a dose of 600 $\mathrm{g} /$ tree gave the highest fruit size and fruit diameter. While [11] stated that calcium fertilizer in the form of dolomite at a dose of $500 \mathrm{~g} /$ tree gave the highest weight of fruit per tree, weight per fruit and number of fruits per tree. Calcium fertilizers other than in solid form can also be given in liquid form such as Calsitor fertilizer, which contains Ca (35\%), $\mathrm{Mg}(15 \%)$ and B (5\%) with the use of 2-4 cc/liter of water [12]. The application of calcitor fertilizer as a source of Ca, $\mathrm{Mg}$ and $\mathrm{B}$ nutrients is expected to have a positive effect on the growth and production of Siam oranges.

The appearance of unattractive citrus peels is not only caused by the lack of certain nutrients but also due to the attack of the dull dotted pathogen, which can reduce the quality of the fruit when marketed. Smooth fruit is certainly a hope for farmers. With good fruit quality, it will increase prices while attracting consumers/buyers [13]. The quality of Siam orange fruit is very important, evenly yellow orange peels have a higher attractiveness than green fruit peels [14]. Symptoms of orange dotted attack can reach 30\%-40\% per hectare. Dull spots are caused by attacks from plant pest organisms. There are several types of pests that cause the fruit to become mottled/unsmooth, among them, scale lice which results in fruit can reduce the quality. The control of scale lice is not only by using chemical pesticides, but also by using biopesticides such as neem leaf extract solution [15]. Neem is a plant can be used as biopesticide that has multifunction's, including insecticides, fungicides, bactericides and nematicides [16]. Biopesticides are pesticides with plant-based ingredients that are environmentally friendly and can replace chemical pesticides [17]. The results of [18] research indicated that the use of neem leaf extract with a concentration of $10 \%$ (100 g fresh neem leaves/l water) was more effective or more efficacious in killing larvae than a concentration of 5\% (50 g fresh neem leaves/l water).

\section{Material and methods}

The study was carried out in Belancan Village, Kintamani District, Bangli Regency, Bali, from December 2020 to July 2021. The study used a Randomized Block Design arranged in a factorial with 2 factors. The first factor was calcitor fertilizer consisting of 4 concentration levels, i.e. $0 \mathrm{cc} / \mathrm{l} / \operatorname{tree}\left(\mathrm{K}_{0}\right) ; 2 \mathrm{cc} / \mathrm{l} / \operatorname{tree}\left(\mathrm{K}_{1}\right), 4 \mathrm{cc} / \mathrm{l} / \operatorname{tree}\left(\mathrm{K}_{2}\right)$, and $6 \mathrm{cc} / \mathrm{l} / \mathrm{tree}\left(\mathrm{K}_{3}\right)$, while the second factor was neem leaf extract consisting of 3 concentration levels, i.e. $0 \% / 0 \mathrm{~g}$ fresh neem leaves/l water/ control $\left(\mathrm{M}_{0}\right), 5 \% / 50 \mathrm{~g}$ fresh neem leaves/l water $\left(\mathrm{M}_{1}\right)$, and 10\%/100 g fresh neem leaves/l water (M). Thus, there were 12 combination treatments and each was repeated 3 times so that 36 sample plants were needed.

Sample plants were selected which were already in production with relatively uniform tree sizes, about 5 years old, located in the same area of ownership (one owner). Plants are maintained by applying proper cultivation methods such as loosening soil, controlling weeds, pruning, eradicating pests and diseases, and fertilizing with compound NPK fertilizer of $100 \mathrm{~g} /$ tree.

Calcitor fertilizer treatment according to concentration $(0,2,4 \mathrm{ml}$ and $6 \mathrm{cc} / \mathrm{l}$ water/tree) was carried out in the morning, sprayed onto the shoots so that all parts of the plant received evenly. During the study, calcitor fertilizer was given 3 times, first when the study was started/before flower formation, second during flowering, and third during fruit enlargement (fruit diameter $\pm 2-4 \mathrm{~cm}$ ). The way to make neem leaf solution; fresh neem leaves were weighed according to the level of treatment, then blended with 1 (one) l of water $+1 \mathrm{ml}$ of alcohol and stirred until smooth. Leaves that have been blended according to the level of concentration are soaked for a full night (12 hours), the next day the soaked ingredients are filtered with a cloth, then added with $1 \mathrm{~g}$ of detergent. The solution was stirred evenly and then sprayed to all parts of the plant according to the treatment. Spraying of neem leaf extract according to the concentration level was carried out 3 times, first when the study was started, second during flowering and third during fruit enlargement.

Variables observed included leaf chlorophyll content, leaf relative ware content (RWC), leaf total sugar content, leaf reducing sugar content, leaf sucrose content, number of flowers formed per tree, number of fruit formed per tree, 
percentage of fruit set, percentage of deciduous fruit. , number of fruit harvested per tree, weight of fruit harvested per tree, weight per fruit, fruit diameter, fruit hardness and total dissolved solids.

Observational data were analyzed by analysis of variance (Anova) according to the design used. If the interaction has significant effect, then it is tested by Duncan's test, whereas if the interaction effect is not significant different then to compare the average value of a single factor, it is tested by BNT test.

\section{Results and discussion}

The results of statistical analysis showed that the interaction between calcitor fertilizer and concentration of neem leaf extract had no significant effect on all observed variables. Meanwhile, in a single factor, the concentration of calcitor and neem leaf extract had a significant to very significant effect on all observed variables. The average values of the observed variables due to the influence of calcitor fertilizer and the treatment of neem leaf extract concentration are presented in Tables 1 to 3.

Calcitor fertilizer with a concentration of $6 \mathrm{cc} / \mathrm{l} /$ tree gave the highest harvested fruit weight per tree $(14.37 \mathrm{~kg})$ or increase of $40.74 \%$ than that of control $(10.21 \mathrm{~kg}$ (Table 1 ). The increase of the weight of fruit per tree at a concentration of calcitor fertilizer of $6 \mathrm{ml} / \mathrm{l} /$ tree was supported by an increase the number of fruit per tree, fruit diameter and weight per fruit, which were 106.44 pieces; $6.89 \mathrm{~cm}$ and $114.08 \mathrm{~g}$, or an increase of $27.56 \% ; 12.58 \%$ and $7.54 \%$, respectively, than those of the control. The increase of the number of fruit per tree was supported by the number of flowers per tree, which was 159.78 buds or an increase of $47.34 \%$ than that of control. The increase of number of fruit per tree was not only supported by the increase of number of flowers per tree but also by the development of flowers into fruit, thereby increasing the percentage of fruit set. In the calcitor fertilizer concentration of $6 \mathrm{cc} / \mathrm{l} /$ tree, the fruit set was $84.28 \%$, significantly higher than that of control, which was $70.56 \%$ only (Table 2 ).

Table 1 Effect of calcitor fertilizer and concentration of neem leaf extract on fruit diameter, weight per fruit, and number of fruits per tree and weight of fruit per tree

\begin{tabular}{|c|c|c|c|c|c|}
\hline Treatments & $\begin{array}{l}\text { Fruits diameter } \\
\text { (cm) }\end{array}$ & $\begin{array}{l}\text { Weight per } \\
\text { fruit (g) }\end{array}$ & $\begin{array}{l}\text { Number of fruits } \\
\text { per tree (g) }\end{array}$ & $\begin{array}{l}\text { Fruit weight } \\
\text { per tree (kg) }\end{array}$ & $\begin{array}{l}\text { Total dissolved } \\
\text { solids (\%) }\end{array}$ \\
\hline \multicolumn{6}{|c|}{ Calcitor Fertilizer (K) } \\
\hline $\mathrm{K}_{0}(0 \mathrm{ml} / \mathrm{l} /$ tree $)$ & $6,42 \mathrm{a}$ & $106,08 \mathrm{~b}$ & $83,44 \mathrm{c}$ & $10,21 \mathrm{~b}$ & $7.96 \mathrm{c}$ \\
\hline $\mathrm{K}_{1}(2 \mathrm{ml} / \mathrm{l} /$ tree $)$ & $6,58 \mathrm{a}$ & $108,61 \mathrm{~b}$ & $96,44 \mathrm{~b}$ & $12,14 \mathrm{~b}$ & $9.40 \mathrm{~b}$ \\
\hline $\mathrm{K}_{2}(4 \mathrm{ml} / \mathrm{l} /$ tree $)$ & $6,74 \mathrm{a}$ & $110,14 \mathrm{ab}$ & $99,00 \mathrm{~b}$ & $13,55 \mathrm{a}$ & $11.26 \mathrm{a}$ \\
\hline $\mathrm{K}_{3}(6 \mathrm{ml} / \mathrm{l} /$ tree $)$ & $6,83 \mathrm{a}$ & $114,08 \mathrm{a}$ & $106,44 \mathrm{a}$ & $14,37 \mathrm{a}$ & $11.52 \mathrm{a}$ \\
\hline BNT $5 \%$ & - & 4,97 & 5,56 & 1,49 & 0.34 \\
\hline \multicolumn{6}{|c|}{ Neem Leaf Extract Concentration (M) } \\
\hline $\mathrm{M}_{0}(0 \%)$ & $6.52 \mathrm{a}$ & $98,89 \mathrm{~b}$ & $63,58 \mathrm{c}$ & $8,98 \mathrm{c}$ & $7.61 \mathrm{~b}$ \\
\hline $\mathrm{M}_{1}(5 \%)$ & $6,79 \mathrm{a}$ & $112,85 \mathrm{a}$ & $98,08 \mathrm{~b}$ & $12,70 \mathrm{~b}$ & $10.42 \mathrm{~b}$ \\
\hline $\mathrm{M}_{2}(10 \%)$ & $6,80 \mathrm{a}$ & $117,44 \mathrm{a}$ & $107,73 \mathrm{a}$ & $16,04 \mathrm{a}$ & $10.83 \mathrm{a}$ \\
\hline BNT 5\% & - & 5,74 & 6,43 & 1,58 & 0.39 \\
\hline
\end{tabular}

The higher number of fruit per tree and weight per fruit at a concentration of calsitor $6 \mathrm{cc} / \mathrm{l} /$ tree was increase the weight of fruit per tree. This was closely related to the higher value of the relative water content (RWC) of leaves at the level of calcitor fertilizer with a concentration of $6 \mathrm{cc} / \mathrm{l} /$ tree. In Table 3, it can be seen that the leaf RWC on calcitor fertilizer with a concentration of $6 \mathrm{cc} / \mathrm{l} /$ tree was $84.75 \%$, and significantly higher than that of control with leaves RWC was only $75.21 \%$. The high of leaves RWC showed that calcitor fertilizer can increase the ability of plants to absorb water so that the internal water content of plant tissues increases. Increasing the RWC of leaves cannot be separated from the function of calcitor fertilizer, where calcitor is a liquid fertilizer containing $\mathrm{Ca}$, Mg and Boron. 
Table 2 Effect of calcitor fertilizer and neem leaf extract concentration on number of flowers per tree, percentage of fruit-set, percentage of fruit drop per tree, leaf chlorophyll content and leaf relative water content

\begin{tabular}{|c|c|c|c|c|}
\hline Treatments & $\begin{array}{c}\text { Number of } \\
\text { flowers per tree } \\
\text { (pieces) }\end{array}$ & $\begin{array}{c}\text { Percentage } \\
\text { Fruit-set per tree } \\
(\%)\end{array}$ & $\begin{array}{l}\text { Percentage of } \\
\text { fruits drop per } \\
\text { tree }(\%)\end{array}$ & $\begin{array}{l}\text { Chlorophyll } \\
\text { content of } \\
\text { Leaf (SPAD) }\end{array}$ \\
\hline \multicolumn{5}{|c|}{ Calcitor Fertilizer $(\mathrm{K})$} \\
\hline $\mathrm{K}_{0}(0 \mathrm{ml} / \mathrm{l} / \mathrm{tree})$ & $108,44 \mathrm{~d}$ & $70,56 \mathrm{~b}$ & $18,56 \mathrm{a}$ & $58,70 \mathrm{~b}$ \\
\hline $\mathrm{K}_{1}(2 \mathrm{ml} / \mathrm{l} /$ tree $)$ & $121,44 \mathrm{c}$ & $73,46 \mathrm{bc}$ & $16,22 \mathrm{ab}$ & $60,65 \mathrm{~b}$ \\
\hline $\mathrm{K}_{2}(4 \mathrm{ml} / \mathrm{l} /$ tree $)$ & $139,44 \mathrm{~b}$ & $77,89 \mathrm{~b}$ & $15,89 \mathrm{~b}$ & $66,44 \mathrm{a}$ \\
\hline $\mathrm{K}_{3}(6 \mathrm{ml} / \mathrm{l} /$ tree $)$ & $159,78 \mathrm{a}$ & $84,28 \mathrm{a}$ & $13,44 \mathrm{~b}$ & $69,30 \mathrm{a}$ \\
\hline BNT 5\% & 12,98 & 5,92 & 2,56 & 4,26 \\
\hline \multicolumn{5}{|c|}{ Neem Leaf Extract Concentration (M) } \\
\hline $\mathrm{M}_{0}(0 \%)$ & $81,33 \mathrm{c}$ & $62,85 \mathrm{c}$ & $21,92 \mathrm{a}$ & $60,79 \mathrm{~b}$ \\
\hline$M_{1}(5 \%)$ & $127,17 \mathrm{~b}$ & $79,51 \mathrm{~b}$ & $17,83 \mathrm{~b}$ & $64,26 \mathrm{ab}$ \\
\hline $\mathrm{M}_{2}(10 \%)$ & $148,33 \mathrm{a}$ & $87,28 \mathrm{a}$ & $8,33 \mathrm{c}$ & $66,26 \mathrm{a}$ \\
\hline BNT 5\% & 14,99 & 6,84 & 2,96 & 4,92 \\
\hline
\end{tabular}

Numbers followed by the same letter in the same treatment and column show no significant difference in the $5 \%$ BNT test.

Table 3 Effect of calcitor fertilizer and neem leaf extract concentration on leaf relative water content, total sugar, reducing sugar and sucrose content of leaf

\begin{tabular}{|c|c|c|c|c|}
\hline Tretamnets & $\begin{array}{c}\text { Leaf relative } \\
\text { water content } \\
\text { /RWC (\%) }\end{array}$ & $\begin{array}{c}\text { Total sugar } \\
\text { content of leaf } \\
(\%)\end{array}$ & $\begin{array}{c}\text { Reducing sugar } \\
\text { content of leaf } \\
(\%)\end{array}$ & $\begin{array}{c}\text { Sucrose } \\
\text { content of } \\
\text { Leaf (\%) }\end{array}$ \\
\hline \multicolumn{5}{|c|}{ Calcitor Fertilizer (K) } \\
\hline $\mathrm{K}_{0}(0 \mathrm{ml} / \mathrm{l} / \mathrm{tree})$ & $75,21 \mathrm{~b}$ & $12,59 \mathrm{~d}$ & $6,13 \mathrm{c}$ & $6,46 \mathrm{c}$ \\
\hline $\mathrm{K}_{1}(2 \mathrm{ml} / \mathrm{l} /$ tree $)$ & $75,39 \mathrm{~b}$ & $12,76 \mathrm{c}$ & $6,23 c$ & $6,53 \mathrm{c}$ \\
\hline $\mathrm{K}_{2}(4 \mathrm{ml} / \mathrm{l} /$ tree $)$ & 81,45 a & $20,87 \mathrm{~b}$ & $9,95 \mathrm{c}$ & $10,92 \mathrm{~b}$ \\
\hline $\mathrm{K}_{3}(6 \mathrm{ml} / \mathrm{l} /$ tree $)$ & $84,75 \mathrm{a}$ & 23,65 a & $10,88 \mathrm{a}$ & $12,77 \mathrm{a}$ \\
\hline BNT $5 \%$ & 4,34 & 0,44 & 0,44 & 1,64 \\
\hline \multicolumn{5}{|c|}{ Neem Leaf Extract Concentration (M) } \\
\hline $\mathrm{M}_{0}(0 \%)$ & $75,36 \mathrm{~b}$ & $13,59 \mathrm{c}$ & $5,93 \mathrm{c}$ & $7,66 \mathrm{c}$ \\
\hline $\mathrm{M}_{1}(5 \%)$ & $78,08 \mathrm{~b}$ & $18,75 \mathrm{~b}$ & $6,63 \mathrm{~b}$ & $12,12 \mathrm{~b}$ \\
\hline $\mathrm{M}_{2}(10 \%)$ & $83,94 \mathrm{a}$ & $24,40 \mathrm{a}$ & $7,42 \mathrm{a}$ & $16,98 \mathrm{a}$ \\
\hline BNT 5\% & 5,01 & 1,20 & 0,48 & 1,73 \\
\hline
\end{tabular}

Khayat HME et al. and Yadav MK et al. stated that, one of the functions of calcium is to strengthen plants and reduce flower and fruit drop [8] [9]. While the element magnesium increases the formation of chlorophyll which is very important in the photosynthesis process, increases plant productivity so that it can prevent the fall of flowers and fruit. By increasing the internal water content of plant tissue, it can increase growth. both below ground (stimulating root growth and development) and above-ground growth, especially protein preparation, energy transfer, as well as ensuring better plant metabolism processes, especially transportation and allocation of photosynthate. The highest leaf chlorophyll content was obtained in calcitor fertilizer with a concentration of $6 \mathrm{cc} / \mathrm{l} / \mathrm{tree}$, which was $69.30 \mathrm{SPAD}$ compared to the control wtih valeu was 58,70 SPAD only (Table 2). The increased of leaf chlorophyll content causes the 
photosynthesis process increase, the resulting photosynthate is higher which is indicated by the higher content of total sugar, reducing sugar, and sucrose content of leaaf, thus supporting faster fruit enlargement and increasing total dissolved solids. The content of total sugar, reducing sugar, sucrose of leaf and total dissolved solids in plants treated with $6 \mathrm{cc} / \mathrm{l} /$ tree calcitor fertilizer were $23.65 \% ; 10.88 \% ; 12.77 \%$ and $11.52 \%$ brix, respectively, were significantly higher than those of control (Tables 1 and 3). The increase of leaf total sugar content, leaf reducing sugar content, leaf sucrose content and total dissolved solids as a result of higher leaf chlorophyll content and photosynthate produced was positively correlated with increasing fruit weight per tree, number of fruit per tree and weight per fruit compared to control. Higher total sugar content in leaves can reduce fruit drop. These data indicate that the calcitor fertilizer with a concentration of $6 \mathrm{cc} / \mathrm{l} /$ tree can be used to increase the productivity and quality of Siam orange fruit in the off-season because it can increase the percentage of fruit-set, increase the number and weight of fruit per tree.

Treatment of neem leaf extract with a concentration of $10 \%$ gave the highest number of fruits per tree (106.44 pieces) or an increase of $27.56 \%$ than that of control with number of fruits per tree was 83.44 pieces (Table 1). The increase in the number of fruits per tree at a concentration of $10 \%$ was due to the higher number of flowers per tree (159.78 buds), which was significantly different than the treatment with neem leaf extract at concentrations of 5\% and $0 \%$ (Control). The increase in the number of fruits per tree was not only affected by the increase the number of flowers per tree but also by the increase of the percentage of fruit set. The highest percentage of fruit-set (84.28\%) was obtained on neem leaf extract with a concentration of $10 \%$ and it caused a higher fruit weight per tree. Table 1 showed that the weight of fruit per tree at $10 \%$ concentration of neem leaf extract was $14,37 \mathrm{~kg}$ and significantly higher than the control which only produced $10.21 \mathrm{~kg}$ of fruit per tree and at a concentration of $5 \%$ yielded $13.55 \mathrm{~kg}$. The increasing number of fruits per tree, weight per fruit, fruit diameter and fruit weight per tree in the $10 \%$ neem leaf extract concentration showed that neem leaves could increase the production and quality of the Siam orange fruit. Neem is a biopesticide that has multifunction's, including insecticides, fungicides, bactericides and nematicides, so that it can suppress attacks by caterpillars, grasshoppers and whitefly which usually cover shoots, leaves and fruit [15]. Thus, the function of the leaves as a source in the photosynthesis process runs smoothly, the resulting photosynthate increases so that it can reduce competition between fruits for assimilate. According to [19], young shoots, twigs and leaves that are attacked by pests and diseases and which are shaded if not immediately removed or pruned then these organs will become competitors so that physiologically reduces the ability of flowers or fruit to get photosynthate. In this study, plants that were not sprayed with neem leaf extract (control) obtained leaf RWC and leaf chlorophyll values of 75.36\% and 60.75 SPAD, significantly lower than plants sprayed with 10\% neem leaf extract, each of which was only $83,94 \%$ and 66,26 SPAD. The low content of leaf chlorophyll and leaf RWC causes poor metabolic processes, resulting in high flower and fruit drop. Bangerth F. stated that, the low photosynthesis received by flowers and fruits was caused by intense competition between plant organs [20]. In this study, Siam orange plants that were not treated with neem leaf extract concentration gave the highest percentage of young fallen fruit per tree, which was $21.92 \%$ compared to oncentration of $10 \%$, which was $8.33 \%$. The low photosynthate produced by citrus plants that were not treated with neem leaf extract spraying was also evidenced by the low leaf total sugar content, leaf reducing sugar content, leaf sucrose content and total dissolved solids, which were $13.59 \% ; 5.93 \% ; 7.66 \%$ and 7.61\% brix, respectively, and significantly lower than those of on neem leaf extract spraying treatment with a concentration of $10 \%$.

\section{Conclusion}

We conclude that the interaction between calcitor fertilizer and spraying of neem leaf extract concentration had no significant effect on all observed variables. Calcitor fertilizer concentration of $6 \mathrm{cc} / \mathrm{l} /$ tree increased the production and quality of fruits of Siam orange, as reflected by the increase in the number of fruits per tree (106.44 fruit), weight per fruit (114.08 g), fruit weight per tree $(14.37 \mathrm{~kg})$, fruit diameter $(6.89 \mathrm{~cm})$ and total dissolved solids $(11.52 \% \mathrm{brix})$. Spraying neem leaf extract with a concentration of $10 \%$ increased the production and quality of fruits of Siam orange, indicated by the increase in the number of fruit per tree (107.73 fruit), weight per fruit (117.44 g), and weight of fruits per tree $(16.04 \mathrm{~kg})$. ), fruit diameter $(7.58 \mathrm{~cm})$ and total dissolved solids (10.83\% brix) or increased by $69.44 \%$; $18.76 \%$; $78.84 \%$ and $42.31 \%$ than that of control which were 63.58 pieces; $98.89 \mathrm{~g} ; 8.98 \mathrm{~kg}$; and $7.61 \%$ brix, respectively.

\section{Compliance with ethical standards}

\section{Acknowledgments}

The authors are thankful to Warmadewa University, Bali, Indonesia, for funding support in this research.

\section{Disclosure of conflict of interest}

The authors declare no conflict of interest. 


\section{References}

[1] Dimyati A. Prospects and challenges of citrus agribusiness. Agricultural Research and Development Agency. Ministry of Agriculture of the Republic of Indonesia, Jakarta. 2005.

[2] Directorate General of Horticulture, Ministry of Agriculture of the Republic of Indonesia. Volume and value of Indonesian horticulture exports and imports for the 2013-2018 period. Ministry of Agriculture of the Republic of Indonesia, Jakarta. 2019.

[3] Lizia Z. Economic feasibility value of Siam orange farming. Research Institute for Citrus and Subtropical Fruits, Ministry of Agriculture of the Republic of Indonesia. 2014.

[4] Januwiata IK, Dunia IK, Indrayani L. Analysis of marketing channels for orange farming in Kerta Village, Payangan District, Gianyar Regency. E-journal. Undiksha. 2014; 4(1).

[5] Supartha IW, Kesumadewi AA, Susila W, Gunadi IGA, Suardi DPO. Profile of Gianyar Regency oranges 2015. Cooperation between the Gianyar Regency Government and Udayana University. 2015.

[6] Srivastava AK. Integrated nutrient management: concept and application in citrus. Tree and Forest Science and Biotechnology. National research Center for Citrus, Maharashtra, India. 2009; 27.

[7] Garhwal PC, Yadav PK, Sharma BD, Singh RS, Ramni AS. Effect of organic manure and nitrogen on growth yield and quality of citrus in sandy soil of hot arid region. African J. of Agric. Res. 2014; 9(34): 2638-2647.

[8] Khayat HME, Rehiem MAA. Improving Mandarin productivity and quality by using mineral and bio-fertilization. Alex. J. Agric. Res. 2013; 58(2): 141-147.

[9] Yadav MK, Solanki VK. Use of micronutrients in tropical and sub-tropical fruit crops: A review. African Journal of Agricultural Research. 2015; 10(5): 416-42.

[10] Purbiati T,Sugiyarto M, Susanto DA. 2014. Study of fruit thinning in Siamese orange (Citrus nobilis var. Microcarpa Hassk). Agricultural Research and Development Agency, Republic of Indonesia. 2014.

[11] Astiari ANK, Sulistiawati A, Rai IN. Efforts to produce Siamese orange fruit all year through application of flowerinducing substance and calcium fertilizer. International Journal of Research in Engineering and Science (IJRES). ISSN (Online). 2020; 8(11): 69-73.

[12] Anonimus. Brochure the use of liquid calcitor fertilizer produced by PT. Bola Agro Lestari. 2017.

[13] Rimayanti NH. Hasimi, Poerwanto R, Suketi K. Degreening of Siam citrus fruit (Citrus nobilis) at several concentrations and duration of ethylene exposure. J. Hort. Indonesia. August. 2016; 7(2): 111-120.

[14] Muthmainnah H, Poerwanto R, Efendi D. Changes in skin color of three varieties of tangerines with degreening treatment and storage temperature. J. Hort. Indonesia. 2014; 5(1): 10-20.

[15] Pangestuti R, Supriyanto A. Efforts to obtain and maintain Soe tangerine quality through optimizing harvest age and cold storage. 2012 .

[16] Supriyanto A. Technology for productivity and quality improvement of citrus fruits to block imported citrus. Research Institute for Citrus and Subtropical Fruits. Agricultural Research and Development Agency, Ministry of Agriculture of the republic of Indonesia. 2012.

[17] Laba W, Wahyuno D, Rizal M. The role of integrated pest and disease control, organic farming and biopesticides towards environmentally sound and sustainable agriculture. Proceedings of the National Seminar on Organic Agriculture. Bogor. 2014; 18 - 19.

[18] Irfan M. Test of vegetable pesticides against plant disease nematodes. Journal of Agrotechnology. 2016; 6(2): 39 45.

[19] Rai IN, Wiraatmaja IW, Semarajaya CGA, Astiari NKA. Application of drip irrigation technology for producing fruit of salak 'Gula Pasir' (Salacca zalacca var. Gula Pasir) off-season on dry land. Journal of Degraded and Mining Lands Management. 2014; 2(1): 219-222.

[20] Bangerth F. Abscission and thinning of young fruit and their regulation by plant hormones and bioregulators, Plant Growth Regulation. 2000; 31: 43-59. 